\title{
KONTROVERSI SEPUTAR NASKH AL-QURAN
}

\author{
Oleb : M. Abdul Hamid, S.Ag
}

\section{Pendahuluan}

Suatu hari Ali RA. Memasuki sebuah masjicl di Kufah. Di masjicl tersebut, dia melihat seorang lakilaki - yang menurut Al - Suyuuti clalam Al - Itqan adalah seorang qadi - seclang dikelilingi oleh banyak orang. Kepada laki-laki itu diajukan berbagai persoalan. Ketika Ali melihat qaclhi tersebut mencampuradukkan perintah dengan larangan dan ibahah (kebolehan) dengan larangan, Ali pun berkata kepadanya :

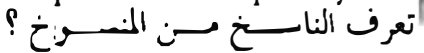
laki - laki itu menjawab : Ticlak. Mendengar jawabàn demikian, Ali berkata kepadanya : Kalau demikian, berarti engkau telah celakal clan mencelakakaln orang lain (Manna' al-gatban, Mababis fi ulumi al-gur'an, bal. 233)

Pertanyalan Ali di atals paling tidak menegaskan urgensi ilmu Nasikh - mansukh sebagai bagian clari ulum Al-qur'an. Sehubungan dengan urgensi Nasikhmansukh ini, pendapat Jalaluddin Assuyuuti dalam kitabnya Al Itqan, yang banyak dikutib oleh para penulis ulum Al-qur'an mengatakan : Para ulama mengatakan bahwa seseorang ticlak boleh menafsirkan kitab Allah (Al-Qur'an) kecuali terlebih clahulu mengetahui ayat yang terdapat dalam Al-qur'an yang mennasikhkan dan yang di nasikhkan. (Jamalu al$\operatorname{din}$ Al-suyutbi, Al-itgan, bal. 21). Karena ticlaklah heran jika para ulam banyak yang membahas persoalan ini.

Naskb yang merupakan masalah yang urgen dan pokok, memiliki komplikasi yang luas dan tinggi dalam theologi dan figh Islam. Paling tidak acla dua jenis naskh yang diterima oleh mayoritas ahli hukum muslim, yaitu naskb Al-bukm wa Al-tilawab (penghapusan hukum maupun tilawah) dan naskb al-bukm duna al-tilawab(penghapusan hukum tetapi ticlak acla teksnya). (lihat Burton, The Collection of The Qur'an, bal.40)

Jenis yang pertamal berhubungan dengan sejumlah ayat yang pada suatusalt dikatakan oleh Nabi sebagai bagian clari Al-qur'an, namun kemudian Nabi sendiri mengatakan bahwa ayat-ayat tersebut ticlak lagi dianggap bagian clari al-qur'an. Di sini penulis ticlak menaruh perhatian pada fenomenaseperti itu karena jelas hal tersebut bukan meruoakan isu hukum. Penulis lebih memusatkan dan memfokuskan pada jenis naskb yang kedua, dimana suatu teks masih manjadi bagian dari al-qur'an tetapi dianggap ticlak berfungsi sebagai cara hukum.

\section{Etimologi Naskh}

Abu AL-afdbol Jamulu Ad-din Al-afrigi Al-misbri dalam kitab Lisan Al-arab talah merinci makna etimologi naskh dengan merujuk kepada bebrapa ayat Al-qur'an, Al-naskh diartikan :

Al-ijalab (penghilangan), seperti firman Allah dallam surat Al-haj ayalt 52 :

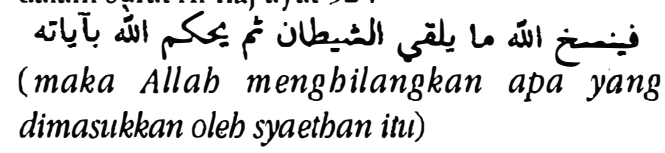
dimasukkan oleb syaetban itu)

Al-tabdil(penggåntian), merujuk kepạda ayat

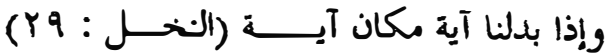


(Dan apabila Kami letakkan suatu ayat di tempat ayat yang lain sebagai gantinya)

At-tabwiil (peminclahan), sebagaimana dapat disinpulkan daripengertian: تناسخ المواريك yang berarti pemindahan warisan dari satu orang kepada orang lain.

- An-naql (penukilan), sebagaimana dalam firman Allah:

إنا كنا نستنسخ ما كنتم تعملون (الجاثية : 9 ( (sesungguhnya Kami telah menyuruh mancatat apa yang telah kalian kerjakan).

Dari arti etimologi An-naskh yang bervariatif di atas, muncullah beberapa panclangan yang akan dijelaskan kemudian.

\section{Terminologi Naskh}

Di tangan kaum Usulliyyin, terminologi naskh diartikan dalam pengertian yang lebih ringkas clan dihindarkan daripengertian yang beragam. Dengan kata lain, jika para musaffir menggunakan kata naskh dengan pengertian yang sangat luas, mencakup naskh yang telah lau, maka kaum usulliyyin membatasinya dengan terminologi yang sangat ringkas. Karenanya naskkh menurut usulliyyin yang sperti yang diungkapkan Ibnu Hajib ialah :

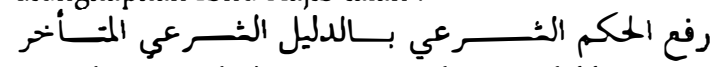
(penghapusan hukum syari'at dengan dalil syari'at yang datang kemudian), definisi ini sebagaimana diungkapkan oleh DR. Subhi Assalih dipandang sebagai definisi yang yang paling cermat, sejalan dengan bahas Arab yang mengartikan kata naskbsama dengan "meniadakan" dan "mancabut". (Subbi Sbalib, "Mababis Fi Ulumi Al-qur'an").

Menyangkut pambatasan pengertian naskh oleh kaum usulliyyin di atas, paling ticlak dapat kita lihat dari tiga hal yang perlu digaris bawahi :

Pertam : kata Raf'u (penghapusan), kedua kata "al-bukmu al-syar'i" (hukum syari'at) dan ketiga kata "bi dalil al-syar'i al-mutaakbkbir" (dengan dalil syari'at yang datang kemudian).

Kata "yarfa'u"(menghapus) dapat mengeluarkan ayat yang tidak menghapus, misalnya ayat yang mentaskhish, karena ayat taskhish pada clasarnya tidak menghapus suatu hukum, melainkan membatasinya sajal. Selanjutnya kata "al-hukmu al-syar'i" menjadi qoyyid, sehingga terbatas kepada hukumhukumsyareat saja. Demikian juga kata "Al-syar'iy", sebenarnya menunjukkan pembatasan yang tegas bahwa selain syari' (pembuat syareat) tidak berhak menaskh hukum syareat. Adapun kata "bidalil alsyar'i" mengandung pengertian bahwa penghapusan hukum karena kematian, gila, clan kelalaian, dapat dikeluarkan dari pengertian naskb yang sebenarnya. Masalahnya kondisi-kondisi seperti ini tidak termasuk dalam katagori dalil syareat. Dan yang terakhir kata "mutakbir" mengeluarkan sesuatu yang ditetapkan secara temporal pada permulaan (lihat "Manabil Alirfan", AL-zargani, bal:191)

Sedangkan Ibnu Hazm memandang Naskblebih jauh lagi, dengan mengatakan naskh yang dimaksud sebagi salah satu bentuk takbsis. Hanya saja yang dia maksudkan bukanalah mentakhsis hukum dari segi keumuman satu lapazd serta maknanya, tetapi mentakhsis hukumdari segi keumuman masa berlakunya hukum tersebut. Dlam hal ini beliau berkata : "bahwa naskh merupakan salah satu bentuk pengecualian (istitsna') karena naskh aclalah mentakhsis masa berlakunya suatu hukum, serta mengecualikan masa berlakunya hukum tersebut pada waktu tertentu". Dengan clemikian clapat dikatakan, bahwa setiap naskb adalah istitsna, tapi tidak semua istitsna disebut naskh. (Al-Ibkam, Ibnu Hazm 4/67).

\section{Nasakh secara umum}

Dalam kitab "manabil al-irfan fi ulum alqur'an", muhammad Abdul Aclhim AlZarqani,membagi naskh kepada enam jenis :

1. naskb Al-Qur'an bil Al-Qur'an, yang dibaginya menjadi naskb at-tilawab wa al-bukm ma'an (bacalan dan hukumnya sama-sama di naskh), naskb al-tilawab duna al-bukm (tulisan di naskh 
dan hukunnyal tetap berlaku) dan naskb al-bukm duna al-tilawab (hukumnya dinaskh dan tulisannya tetap adla dalam Al-Qur'an)

2. Nalskh al-Qur'an bi al-sunnalh

3. Naskh al-sunnah bi Al-Qur'an

4. Naskh as-sunnah bi as-sunnah

5. Naskh al-qiyals wa al-naskh bihi

6. Naskh al-ijmal wal-al-naskh bihi. ( 'manabil al-irfan fi ulum al-Qur'an', Al-Zarqani bal. 2/231)

Diantara jenis naskh diattas yang penulis bahals pacla makalah ini adcalah Naskh Al-Quran bil al-Qur'an yang kedual yaitu : naskb al-bukm duna al-tilawah, hal ini clikarenakan bahwa naskh jenis ini yang paling memungkinkan untuk mendapatkan pembenaran secara aqli dan naqli, kallaupun mengenai keduanya sejak alwal telah lahir pendapat-pendlapat kontroversial.

\section{Pandangan ulama tentang naskh Al-Qur'an}

Sebagaimana yang diutarakan penulis diattas, baliwa pokok masalah yang clibahals ad allah naskb al-hukm duna al-tilawab, maka berikut ini pandlangan-pandangan para ahli hukum Islam (ulamal) tentang naskb jenis ini.

Prinsip naskh jenis ini telah diterima oleh sebagian besar ahli hukum Islam - terlepas clari adlanya perbedaan tentang persoalan, apakah suatu ayat tertentu telah atau belum dihapus oleh alyat-ayat yang lain dan apakah sunnah dapat menghapus hukum alQuran - namun mereka menyepakati naskh itu sendiri. ( Burton "The Collection of the Qor'an " $\mathrm{bal}$ : 49)

Menurut paral ahli hukum perintis, sattu-satunyal jalan untuk mempertemukan sumber-sumber yang secara mencolok bertolak belakang dan bertentangan itu aclalah dengan menganggap ayat-alyat yang lebih alwal dihapus, demi tujuan hukkum, oleh ayat-ayat dan sunnalh masa berikutnya. Prinsip ini menjali alat hukum yang umum digunakan paraia ahli hukum berbagai sistem hukum (mazhab) sampai saat ini.

Meskipun demikian ambigu, namun prinsip naskh lalu diakui para ahli hukum clan clijaclikan landasan konsep syarriahnya. Pertanyaian krusial kital adlalah, apakalh penghapusan teks-teks al-Qur'an yang lebih awal oleh teks-teks al-qur'an berikutnya itu bersifat final clan konklusif? atau masih terbuka untuk dipertimbangkan kembali? jikal seseorang berurusan dengan hukum buattan manusia, masalah itu bisa cepat diselesaikan dan dipechkan dengan meminta penjelasan kepada badlan legislatif untuk konfirmasi tujuan legislatifnya. Tetapi ini tidlak munfkin untuk dilakukan chlam kontek hukum Islam, karena sang legislaturnyal adalah Allah, yang menurut keimanan kita telah memutuskan komunikasi langsung-Nya clengan umat manusia dengan mengutus Nabi terakhir dan menyempurnakan seluruh wahyunya dalam AlQuran. Sehingga konfirmasi apapun yang clapat diperoleh seseorang darrilegislatur clalam kontek Islam harus dijabarkan clari Al-Qur'an clan sunnah Nabi.

Imam Fakbru Al-raji seorang ahli tafsir berpendapat : secara rasional naskb adalah sesuatu yang dibenarkan demikian juga dalam kenyattannya suclah kita dengar clan kital lihat. (Rawai al-bayan, M.Ali Al-Shabuni, b.100). Pendapat ini diperkuat oleh Imam Syafi'i, orang yang pertama kali membahals naskh secara menclalam dalam kitabnya "Risalab alisuul' dan Al-jashosh dalam tafsirnya "Abkamu AlQur'an", demikian juga didukung oleh mayoritas ulama.

Argumentasi yang niereka gunakan adalah sebagai berikut :

1. Firman Allah dalam surat Al-baqaarah ayat 106 :

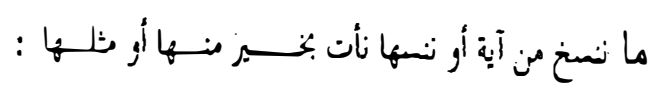

ayat ini dipandlang sebagai dalil konkrik adanyal naskb clalam al-quran.

2. Firman Allah clalam surat An-nahl ayat 101 :

$$
\text { وإذا بدلنا آية مكان آية والله أعلم .ما يترل }
$$

ayat ini sangat jelas sekali adlanyal penggantian padal ayat clan hukum syariat. penggantian iini jugal mempunyai arti penghapusan clan penetapan hukum syari'at, baik tilawah (bacalan) maupun hukum. 
3. Firman Allah dalam surat Al-baqarah ayat 142 dan 144 :

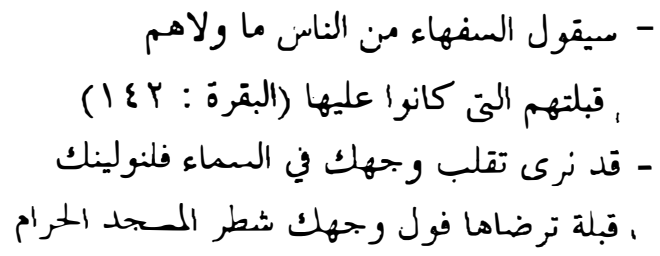

Ayat ini menjelaskan perpinclahan qiblat dari baitu al-maqdis ke ka'bahbaetu al-haram.

(lihat "Abkam Al-Qur'an" karya Al-Jashosh jilid 1 hal. 61 dan "Rawai'Al-bayan", M.Alli Al-shabuni jilid 1 hal.101)

Menurut Al-Zarkasyi ayat yang dinaskh secara hukum tetapi masih tertulis clalam Al-Qur'an terdapat dalam 36 surat. Sedangkan Imam As-suyuti berpendapat, bahwa didalam Al-Qur'an terdapt 20 nash yang dinaskh. Karena setelah diteliti secara mendalam ternyatta nash-nash tersebut tidak dapat dipertemukan. Padahal jika nash-nash tersebut dapat dikompromikan dengan barbagai cara yang memungkinkan, tentu lebih baik daripada men-naskbkannya. Karena dengan naskbnash-nash tersebut tidak berfngsi. Sedang memfungsikan suatu nash dengan jalan mengkompromikan tentu lebih baik daripada membiarkannya tidak berfungsi. (M.Abu Zahrahn "Usul Figh. Hal.188")

Abu Muslim Al-Ashfahani seorang ahli tafsir mu'tazilah yang meninggal pada tahun $322 \mathrm{H}$. dalam kitabnyal "Jami' Al-Ta'wil" menolak adanya naskh dalam Al-Qur'an. penclapat beliau dikuatkan dimasa akhir-akhir ini oleh beberapa ahli ilmu yang terkenal, diantaranya Al- ustadz Asy-syaikh muhammad Abduh, murid besar dari Sayyid Ridho' DR. Taufiq Shidqi dan Al-Ustadz Khudhari. Diantara argumentasi yang mereka gunakan adalah sebagai berikut :

1. Naskh adalah suatu pembatalan hukum. Jika diantara hukum-hukum yang terkandung dalamdalam Al-Qur'an ada yang di naskh, berarti adda ayat-ayat suci Al-Qur'an yang di batalkan. Hal ini tentu bertentangan dengan firman Allah yang berbunyi :

$$
\text { لا بأنه الباطل من بين يديه ولا من خلفه (حم السجدة : Y؟) }
$$

2. Hukum-hukum yang terkandung dalam Al-Qur'an addalah syarr'at yang bersifat abadi, yang berlaku hingga hari kiamat. Dengan demikian tidak layak bila dalam Al-Qur'an terjadi naskh.

3. Kebanyakan hukum yang terdapat Al-Qur'an bersifat kulli (global) dan umum, bukan bersifat juz'i dan khusus. Dengan demikian tidak layak bila terjadi naskh dalam Al-Qur'an.

Adlapun dalil-calil yangdigunakan jumhur sebenarnya tidak memastikan adanya nask. Karena yang dimaksud "ayat" dalam firman Allah dalam surat Al-baqarah ayat 106 adalah : mukjizat yang diberikan Allah kepada seorang nabi yang tidak diberikan kepacla nabi yang lain.

Disamping itu, ayat-ayat yang konon harus dinaskhkan, pada hakekatnya dapat dikompromikan, baik dengan jalan takwil maupun dengan jalan takhsis, yang tentu hal ini lebih baik clari pacla mennaskhkannya. (M.Abu Zabrab, "usul Fiqb", bal. 194)

Kemudian Hasan dalam bukunya "Early Development Islamic juriprudence bal.46" mengatakan : secara lebih segnifikan, terungkap bahwa teori naskb seperti dikembangkan dan diterapkan oleh para ahli hukum tidak mempunyai referensi clari nabi, karena tidak ditemukan informasi apapun dari tentang adanya ayat-ayat yang clihapus clalam Al-Qur'an dalam pengertian penghapusan hukum suatu ayat yang masih menjadi yang masih menjadi bagian dari teks al-qur'an. Inilah mungkin sebabnya mengapa mengapa kita menemukan perbedaan pandangan yang begitu luas dikalangan paral sahabat mengenai ayat-ayat yang clihapus dan masih mengikat dalam Al-Qur'an.

Prof. Mabmoed Taba berpenclapat bahwa mungkin saja, bahkan wajib, untuk memikirkan kembali alasan dan penerapan naskb untuk mencapai derajat yang mendesak akan pembaruan hukum 
Islam. Dia mengatakan :

"Evolusi Syari'ah, secara sederhana adalah evolusi clengan perpinclahan clari satu teks Al-Qur'an ke teks yang lain, clari satu teks yang pantas untuk mengatur abad ke tujuh clan telah cliterapkan, kepada satu teks yang pacla waktu itu terlalu maju clan karena itu clibatalkan. Allh berfirman : "kapan saja Kami mennaskh duatu ayat, atau menundanya, Kami datangkan ayat yang lebib baik daripadanya, atau ayat yang sebanding dengannya."kalimat "Kami datangkan ayat yang lebib baik" tadi berarti membatalkan atau mencabut, clan kalimat "atau. menundanya" berarti menunda pelaksanaan atau penerapannya. Kalimat "Kamidatangkan ayat yang lebib baik" berarti menclatangkan ayat yang lebih clekat dengan pemahaman masyarakat dan lebih sesuai dengan situasi mereka ketimbang ayat yang ditunda, "atau ayat yang sebanding dengannya" berarti mengmbalikan ayat yang sama ketika waktu memungkinkan untuk menerapkannya. Ini seolah-olah penghàpusan ayat-ayat itu menjadi ayat yang pantas dan operatif dan clapt diimplementasikan, sedangkan ayat-ayat yang telah cliimplementasikan pacla abad ke tujuh menjadi terhapus - ini adalah alasan penghapusan - ( denagn kata lain, ticlak dimaksuclkan sebagai) penghapusan yang final clan konklusif, melainkan semata-mata penundaan hingga wktunya tepat.

Dalam evolusi ini kami mempertimbangkan alasan di luar suatu teks. Jika ayat tambahan, yang digunakan untuk menolak ayat utama pacla abad ketujuh, telah memfungsikan tujuannya secara sempurna dan menjadi ticlak relevan bagi era baru, abad keduapuluh, kemudian waktu telah memungkinkan menghapuskannya dan untuk ayat utma di berlakukan. Dengan cara ini, ayat utama kembali sebagai teks yang operatif pacla abad kecluapuluh dan menjadi basis legislasi yang baru.

Inilah yang dimaksud dengan evolusi syari'ah. Satu peralihan clari satu teks yang telah memfungsikan tujuannya clan digantikan dengan teks lain yang clitunda hingga waktunya tepat. Oleh karena itu, evolusi bukan sesuatu yang ticlak realistis atau prematur, bukan pula menujukkan suatu pandangan yang naif dan mentah. Ia semata-mata hanyalah perolehan clari satu teks ke teks yang lain. (lihat terjemahan, "Toward an Islamic Reformation", Abdullab Abmed Anna'im, bal.155).

\section{Kesimpulan}

Dari pembahasan di ats, ada beberapa point yang clapat penulis simpulkan, yaitu :

1. Pengetahuan tentang naskb dan Manssukb aclalah salahsatu hal yang urgen untuk memahami AlQur'an sebagai bagian clari ulumu Al-Qur'an

2. Para ahli berpenclapat; bahwa satu-satunya jalan untuk mempertemukan sumber-sumber yang secara mencolok bertolak belakang dan bertentangan itu adalah dengan menganggap ayatayat yang lebih awal di hapus, demi tujuan hukum, oleh ayat-ayat dan sunnah masa berikutnya. perinsip ini menjadi alat hukum yang umum digunakan para ahli hukum berbagai sistem hukum (mazhab) sampai saat ini.

3. Mengkompromikan kembali nash-nash yang clianggap mensukh lebih baik clari pacla ticlak memfungsikannya

4. Teori "Evaluasi Syari'ah" merupakan alternatif mempertemukan kembali nash-nash yang dianggap berlawanan untuk menghilangkan aclanya naskh al-hukm duna al-tilawah.

Demikian dengan ringkas kami terangkan dan paparkan kontroversi ulama seputar naskb Al-Qur'an. persoalan Naskb - mansukb boleh jadi tetap sebagai persoalan kontroversal. Tetapi, ia ticlak boleh mengurangi keimanan kita kepacla karakteristik AlQur'an yang harus cliposisikan secara proporsonaloleh setiap orang yang mengaku mengimani Al-Quran. Seperti tidak bolehnya mengurangi Mujadalab dan syabadab kita ntuk mengaktualisasikan nilai-nilainya dalam segala hal. Memang Al-Qur'an ticlak cukup hanya dijadikan landasan moral. Wallabu A'lam bi ash-shawab. 


\section{DAFTAR BACAAN}

Abclullah Ahmed An-nai'm, "Toward In Islamic Reformation", Terjemahan, LKiS Yogyakarta 1994

Abu Afdhal Jamaluddin Al- Afriai Al-Mishri, "Lisan Al-Arab", Darul fikri, Bairut 1994 Al-Qur'an dan Terjemabannya, Departemen Agama RI. Jakarta 1989

Al-Zarqani,., "Manabil Al-Irfan Fi Ulumi Al-Qur'an", Darul Fikr, Bairut,1990

DR. Subhi Shaleh, "Mababis FI Ulumi Al-Qur'an”, Dinamika Barokah Utama, Jakarta Jalaludin Asy-suyuyuti, Al-Itgan FI Ululmi Al-Qur'an", Darul Fikr,bairut

M. Alli Ash-sahbuni, "Rawai'u Al-Bayan Fi Tafsiri Ayati Al-Abkam",Darul Fikr, Bairut 1985

M. Alwi Al-Maliki, "Zubdab Al-Itgan FI ulumi Al-Qur'an ", Darul Insan, Qahirah, 1981

M. Hasbi Ash-Shidiqi, Sejarab dan Pengantar Ilmu Al-Qur'an/Jafsir", bulan Bintang, Jakarta 1994

Manna'i Al-Qathan, Mababis Fi Ulumi Al-Qur'an", Darul Fikr, Labnon, bairut

Muh. Abu Zahrah, "Usul Figh", Darul Fikri Al-Arabi 